\title{
ARCHAEOLOGY AND PUBLIC PERCEPTION OF A TRANS-SCIENTIFIC PROBLEM: DISPOSAL OF TOXIC WASTES IN THE UNSATURATED ZONE
}



ARCHAEOLOGY AND PUBLIC PERCEPTION OF A TRANS-SCIENTIFIC PROBLEM: DISPOSAL OF TOXIC WASTES IN THE UNSATURATED ZONE

By Isaac J. Winograd

U.S. GEOLOGICAL SURVEY

Open-file Report 86-136

Reston, Virginia 


\section{UNITED STATES DEPARTMENT OF THE INTERIOR}

DONALD PAUL HODEL, Secretary

GEOLOGICAL SURVEY

Dallas L. Peck, Director

For additional information write to:

\section{J. Winograd}

Water Resources Division

U.S. Geological Survey

National Center (MS 432)

Reston, VA 22092
Copies of this report can be purchased from:

Open-file Services Section Western Distribution Branch U.S. Geological Survey Box 25425, Federal Center Denver, Colorado 80225

Telephone: (303) 236-7476 
Abstract-1-1

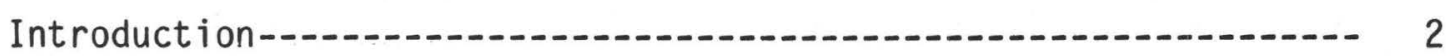

Unsaturated Zone Disposal of Solidified Toxic Wastes-.-.-.-.---.-- 4

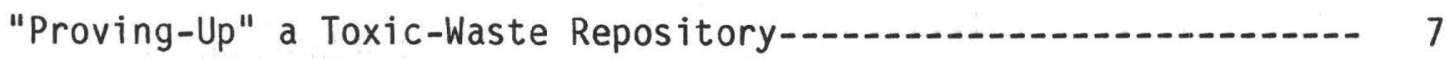

Potential Applications of Archaeology to Toxic-Waste Disposal---- 12

Efficacy of thick unsaturated-zone environments for isolation of solidified toxic wastes-...............-..- 12

Future human intrusion into toxic-waste burial sites---.----- 20

Identification of durable natural and man-made materials---- 22

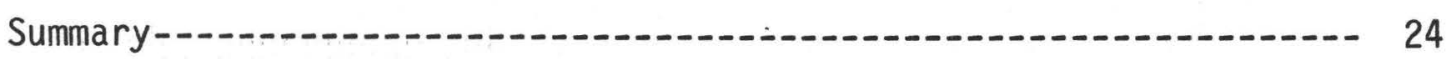

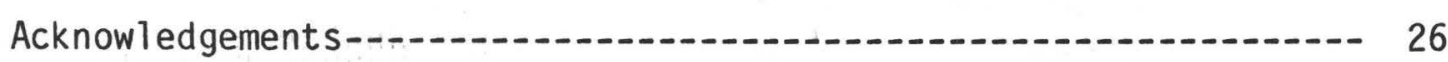

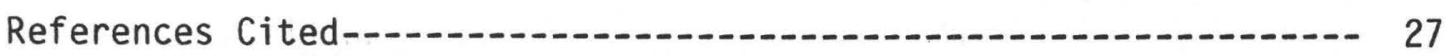





\section{ARCHAEOLOGY AND PUBLIC PERCEPTION OF A \\ TRANS-SCIENTIFIC PROBLEM: DISPOSAL OF}

TOXIC WASTES IN THE UNSATURATED ZONE

By Isaac J. Winograd

\section{ABSTRACT}

Prediction of the effects of toxic-waste disposal on the environment over periods of millenia to hundreds of millenia is a trans-scientific problem, that is, one not fully addressed by quantitative scientific and engineering endeavors. Archaeology is a pertinent adjunct to such "predictions" on several fronts. First, and foremost, the archaeological record demonstrates that delicate as well as durable objects buried in thick unsaturated zones of arid and semi-arid environments may survive intact for millenia to tens of millenia. This "as built" record of successful preservation of Late Paleolithic to Iron Age artifacts provides independent support for the tentative favorable conclusions of earth scientists regarding the general utility of thick unsaturated zones for toxic-waste isolation. By analogy with the archaeological record, solidified toxic wastes of low solubility that are buried in arid unsaturated zones should remain isolated from the environment indefinitely; modern man presumably should be able to improve upon the techniques used by his ancestors to isolate and preserve their sacred and utilitarian objects. Second, archaeologic evidence pertinent to the fate of objects buried in unsaturated zones--though qualitative in nature and subject to the limitations of arguments by analogy--is meaningful to the public and the courts who, along with some scientists and engineers, are reluctant to rely exclusively on computer-generated "predictions" of the effects of buried toxic wastes on the environment. Third, the archaeological record issues a warning that our descendants may intrude into our waste disposal sites and that we must therefore take special measures to minimize such entry, and if it occurs, to warn of the dangers by means of a variety of symbols. And fourth, archaeology provides a record of durable natural and man-made materials which may prove to be suitable for encapsulation of our wastes and from which we can construct warning markers which will last for millenia. For these four reasons, it appears essential that archaeologists join with earth scientists, and other scientists and engineers, in addressing the likely fate of solidified toxic wastes buried in the thick (200-600 m) unsaturated zones of arid and semi-arid regions. Indeed, the input of archaeology might be crucial to public acceptance of even the most carefully chosen and technically sound waste repository. 


\section{INTRODUCTION}

Alvin Weinberg (1985) utilized the phrase "trans-scientific" to describe certain environmental problems which, while requiring the close attention of scientists and engineers, are not likely to be solved by science. For example, in matters such as unravelling the health effects of low-level ionizing radiation--in an environment containing numerous other potential mutagens and carcinogens--Weinberg (1985) suggested that both the public and governmental regulators might have to lower their expectations of quantitative answers from science and engineering. The disposal of certain highly toxic wastes, such as high-level radioactive waste, is another trans-scientific issue. Earth scientists, in collaboration with chemical engineers, material scientists, and others, are being called upon to "predict" the environmental fate of high-level radioactive wastes for periods of millenia to hundreds of millenia! Such "predictions"--to be generated by complex interdisciplinary models which synthesize knowledge from numerous disciplines--are preforce tenuous because a data base with which to calibrate such models does not now exist, nor is it likely to exist prior to the filling and sealing of the first waste repository. Simply put, we do not have the geotechnical experience with which to evaluate the reliability of model predictions even for periods of centuries. The time dimension, alone, relegates high-level radioactive waste disposal to the realm of a trans-scientific issue. 
This paper was written to suggest that while quantitative analysis of the fate of buried toxic wastes is unlikely, by itself, to prove adequate, highly pertinent qualitative evidence bearing on this complex matter resides in the field of archaeology. Such evidence may enable the scientist, regulator, and the public to convince themselves that solidified toxic wastes may be safely disposed of in carefully selected underground environments, even in the absence of quantitative "proof". The author hopes that this paper will generate interest among archaeologists in applying their knowledge to the burgeoning, global, and trans-scientific problems of toxic-waste disposal. 
UNSATURATED ZONE DISPOSAL OF SOLIDIFIED TOXIC WASTES

Toxic wastes, whether of industrial, agricultural, or municipal origin, are being disposed of in two principal ways (National Research Council, 1983, fig. 2): (a) by conversion to less hazardous or nonhazardous forms by means of incineration, chemical neutralization, biological alteration, industrial recycling, or dilution; and (b) by "perpetual" storage, by means of placement in surface impoundments or landfills, injection into brine aquifers, and burial (in solid form) in thick unsaturated zones 1 in arid regions. As a result of recent dramatic failures of some early land-disposal efforts--Love Canal being a prime example--considerable attention is being focused on waste conversion rather than on land-disposal methods. Yet, not all wastes are amenable to waste conversion, and some converted wastes still leave a volumetrically small, but toxic residue requiring "perpetual" storage or disposal. Thick (greater than 150 meter) unsaturated zones, in arid and semi-arid regions, have been identified (Winograd, 1972, 1974, 1981; Wacks, Kuck, Matloubieh, and McGray, 1981; Roseboom, 1983; Wallenburg, Yang, and Kerbin, 1983; and National Research Council, 1983) as potentially favorable environments for the disposal of the most toxic of the Nation's wastes, particularly solidified high-level radioactive waste. It is in the evaluation and future utilization of thick unsaturated zones--which

1 The unsaturated zone is the soil and underlying rock between the land surface and the water table. In portions of the Southwest, such zones are hundreds of meters thick permitting burial of the wastes at depths precluding exhumation by erosion. 
the National Research Council (1983, p. 71) referred to as a "National asset in achieving a solution to the waste-disposai problem"--that archaeology can make several major contributions to be outlined below.

The unsaturated zone in many parts of the Southwest exceeds 150 meters in thickness, and zones this thick encompass a minimum volume estimated to be about 22,000 cubic kilometers (M. S. Bedinger, U.S. Geological Survey, oral communication, 1984). As a direct result of the search for sites suitable for disposal of radioactive wastes, it became apparent in the 1970's, that unsaturated zone environments had excellent potential for isolating solidified toxic wastes from the hydrosphere for millenia to perhaps hundreds of millenia. The apparent attractive features of these arid and semi-arid environments for waste isolation, as identified in preliminary studies (Winograd, 1972, 1974, 1981; Roseboom, 1983), included: (a) low moisture flux; (b) high sorptive capacity of selected rocks for radionuclides; and (c) the opportunity to utilize natural and man-made "capillary barriers" and other engineering structures to divert the meager moisture flux from contacting the wastes. Potential concerns about the long-term efficacy of such environments were also identified, including: (a) the potential for future human intrusion into relatively shallow burial sites; (b) the increase in recharge and rise of water table that might accompany future pluvial climates; (c) effects of erosion, and, in some areas, tectonism; and (d) the absence of detailed studies of the soils physics of such environments. Briefly, thick unsaturated zones appear very attractive for the permanent disposal of solidified toxic wastes, particularly those not amenable to other treatment, because water 
flow, the chief pollutant-transporting mechanism, is minimal or absent. Detailed studies of the soils physics, geochemistry and rock mechanics of these environments are in progress at several universities, at the Sandia, Los Alamos, and Livermore National Laboratories, and at the U.S. Geological Survey.

While the emphasis in this report is on waste disposal in arid and semi-arid unsaturated zones, the archaeological record (see below) clearly suggests that even in humid zones such environments have potential for isolation of solidified toxic wastes of low solubility from the hydrosphere. How long must buried toxic wastes be isolated from the hydrosphere and biosphere? In the case of high-level radioactive wastes, figures of several hundreds of years to longer than a million years appear in the literature (Bredehoeft and others, 1978; Cohen, 1982; and National Academy of Sciences, 1983), reflecting differing opinions about the relative importance of radionuclides of greatly varying halflives. However, in the case of nonradioactive toxic wastes--for example, compounds of lead or arsenic--isotopic decay is not present to reduce the waste concentration with time. In this case, we would like to assure ourselves that the wastes will not contaminate the environment at least for periods of tens of millenia. 


\section{"PROVING UP" A TOXIC-WASTE REPOSITORY}

Selection of new sites for disposal of the Nation's most toxic wastes, such as high-level radioactive wastes, will be a lengthy process involving detailed geotechnical investigations, numerous public hearings, and most likely litigation. The nature of the geotechnical work being done with regard to the disposal of high-level radioactive wastes is outlined below; similar studies will undoubtedly be required prior to the disposal of other types of toxic wastes.

To hedge against uncertainties, the currently accepted philosophy of radioactive-waste disposal is one of "multiple barriers" or, in engineering parlance, "defense in depth" (Interagency Review Group, 1978). That is, a redundancy in safety is sought by utilizing a variety of means to ensure isolation of the wastes from the hydrosphere and biosphere. In the case of high-level radioactive waste, four barriers to radionuclide migration are receiving attention. The first barrier is a waste form of very low solubility, such as glass. To hedge against possible radionuclide release caused by devitrification, the glass-bearing waste additionally may be put into a metallic or ceramic cannister and even surrounded by clay or zeolite minerals. (The resulting product is referred to as a "waste package"). A second major line of defense is a host rock that ideally contains little ground water to dissolve radionuclides from the waste package. A third line of defense is the sorptive capacity of host-rock minerals for the radionuclides; sorption can result in nuclide migration rates one to several orders of magnitude slower than the velocity 
of the transporting vadose 2 or ground waters. The fourth line of defense is the occurrence beneath (in the case of the unsaturated zone) or within (in the case of saturated zone) the site of slow moving ground water which is remote from points of present or likely future utilization. The relative importance of these barriers is, not surprisingly, highly site specific.

The ability of each of these perceived barriers to prevent or retard radionuclide migration is undergoing extensive studies at three sites currently being evaluated for the disposal of high-level radioactive wastes; namely the Waste Isolation Pilot Plant (WIPP) site in Permian aged salt beds of southeastern New Mexico, the Basalt Waste Isolation Plant (BWIP) site in Tertiary basalts at Hanford, Wash., and the Yucca Mountain site in unsaturated Tertiary welded tuff at the Nevada Test Site. A recent review, under one cover, of some of this research is presented by the Materials Research Society (1984). The general goals of these site studies are threefold: (a) to obtain a detailed understanding of the numerous variables affecting the performance of each of the cited barriers. For example, a study of the sorption of radionuclides during movement through the host rock involves detailed knowledge of their rate of release from the waste form, rock mineralogy and physical properties, vadose and ground water velocity, vadose and ground water chemistry, state of the radionuclides (dissolved or colloidal, and, if dissolved, their valence state), nuclide solubility, the relative importance of ion

2 Vadose waters are those occurring in the unsaturated zone. 
exchange, fixation, and other sorption mechanisms, and lastly the alteration of each of the above by the strong temperature and radiation fields expectable in a high-level waste repository; (b) quantification of the observations made for each barrier by means of appropriate physicochemical models; and (c) coupling of the quantitative models developed for each barrier into a mega-model to be utilized for prediction of the rate of migration of radionuclides from the site and their concentration in ground and surface waters, and food chains over periods of millenia and beyond (see Tyler and others, 1984, Garisto and Lyon, 1984; and Ross, 1986, for outlines of such studies). All three of these goals are formidable, but we restrict our discussion only to the feasibility of the last goal, namely that of long-term prediction of the fate of radionuclides in the environment surrounding the waste repository.

There is a relatively small, but highly instructive literature on prediction in the earth and other natural sciences. This literature may be divided into two groups: studies that examine the subject from a philosophical viewpoint, and studies that emphasize the pragmatic aspects. A brief review of this literature was presented by the author and by N.J. Trask in Bredehoeft and others (1978). Study of this literature does not lead to much confidence in the ability of mega-models (or even of the component models for each barrier) to accurately predict the behavior of buried toxic wastes even over periods of a few millenia. There are three principal reasons for this: (a) an empirical data base does not exist with which to calibrate the model. Moreover, future assembly of such a data base in any reasonable time span appears to be 
out of the auestion. Calibration would require field information over a period long enough to test the processes of solution, tránsport, adsorption, and chemical reaction that are postulated in the models. Given the low solubilities of proposed waste forms. the accumulation of such data in the field would itself require decades or perhaps centuries. Thus it seems that. from the nature of the exercise, predictions of the transport and fate of these materials in the environment will alwavs be based on calculations with uncalibrated models; (b) the record of prediction in the earth sciences, includina soil mechanics, the oldest quantitative branch of earth science, is a mixed bag. Most engineering geologic "predictions," in any event, are autopsies; predictions made before the event are not as common. Papers by Lambe (1973), Peck (1980), and Leonards (1982), are particularly instructive reviews of prediction in the geotechnical sciences; and (c) there are strong philosophical arguments for believing that explanation and prediction in the natural sciences are not symmetrical; that is, understanding of a process (hardly an easy undertaking) does not mean that prediction is attainable (Bradbury and ? others, 1983; Scriven, 1959; Mayr, 1961; and Simpson, 1970).

Stated in the simplest of terms, our ability to evaluate predictions of the fate of buried toxic wastes over millenia, or even centuries, is severely limited by our lack of experience. Hence, predictions of the fate of toxic wastes, whether generated by complex or by simple physicochemical models, must be viewed with great caution. Such predictions involve conditions considerably more complex than those commonly tackled in geotechnical engineering, such as estimations of the settling of a 
bridge or skyscraper foundation or of the drawdown of water level in a heavily stressed aquifer (Konikow and Patten, 1985). Briefly, the task of predicting the long-term effects of buried toxic wastes on the hydrosphere and biosphere is an excellent example of the trans-scientific issues discussed by Weinberg (1985). As succinctly stated by him (1985, p. 60):

\begin{abstract}
"Science deals with regularities in our experience; art deals with singularities. It is no wonder that science tends to lose its predictive or even explanatory power when the phe nomena it deals with are singular, irreproducible, and one of a kind--in other words, rare. Although science can often analyze a rare event after the fact--for example, the extinction of dinosaurs during the Cretaceous-Tertiary period following the presumed collision of the earth and an asteroid--it has great difficulty predicting when such an uncommon event will occur."
\end{abstract}

What then are we to do? Certainly, process studies and modeling efforts related to understanding the fate of buried wastes must go forward, because such efforts frequently identify the weakest links in our knowledge of a system and can also lead to an early disqualification of marginal sites proposed for waste disposal. But, another endeavor is of equal importance. Synthesis of the archaeological record of man's past utilization of the unsaturated zone for the preservation of objects can provide an invaluable empirical "data base" pertinent to the transscientific problem of toxic waste disposal.

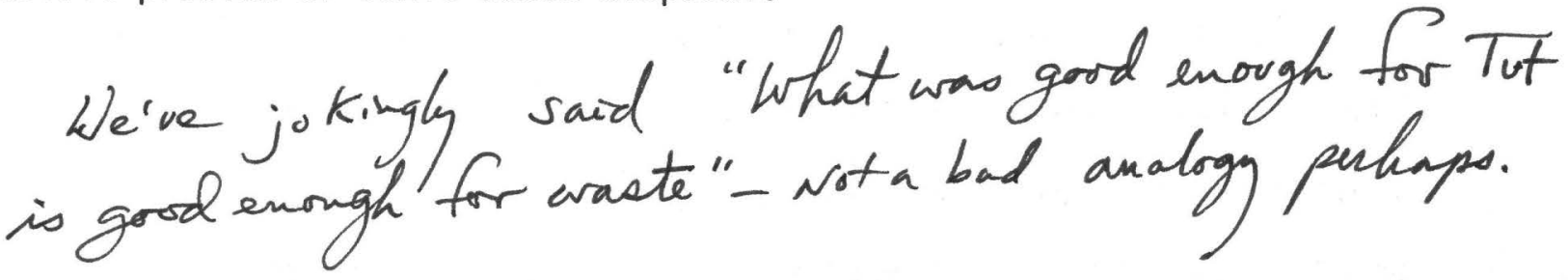


POTENTIAL APPLICATIONS OF ARCHAEOLOGY TO TOXIC-WASTE DISPOSAL

Archaeological science can meaningfully contribute to an evaluation of sites for "perpetual" toxic-waste disposal in three ways: (a) by addressing the general efficacy of unsaturated zones as environments suitable for isolating solidified toxic waste from the hydrosphere and biosphere over times of millenia to tens of millenia; (b) by addressing the issue of future human intrusion; and $(c)$ by identifying durable natural and man-made objects suitable for encapsulation of wastes or for use as warning markers. The last two topics also have application to the disposal of solidified toxic wastes below the water table, whereas the first topic--of principal concern in this paper--applies exclusively to disposal of wastes in unsaturated zones. These three topics are interrelated, but for convenience they are discussed separately.

\section{Efficacy of Thick Unsaturated-Zone Environments for Isolation of Solidified Toxic Wastes}

The archaeological record of Late Paleolithic man (about 40,000 to 10,000 B.C.) is largely preserved in caves and rock shelters, whereas the record of Neolithic to Iron Age man (about 8,000 to 1,000 B.C.) is increasingly preserved in man-made structures. A very brief outline of this record, presented below, demonstrates how well delicate, as well as durable objects, emplaced in the unsaturated zone by our ancestors--or accidentally buried in this environment--have survived over periods of millenia to tens of millenia. 
Late Paleolithic man was probably unaware that the caves that sheltered him would provide preservation of his lifestyle. Such caves, even those in the humid zone, have yielded the oldest and among the most famous of archaeological finds (Leakey, 1981), including: molded clay bison from the French cave, Le Tuc d'Audoubert (about 15,000 years 01d); ivory animal statuettes from the German Vogelherd cave (about 32,000 years old); and of course the famous ice-age cave art as much as 35,000 years old. These caves provided a well-drained environment with relatively constant annual temperature and humidity--conditions apparently favorable for preserving artifacts despite the presence of oxidizing conditions and high humidity.

The archaeological record of Neolithic to Iron Age man contains numerous examples of preserved delicate objects that were buried, intentionally or unintentionally, in presently arid and semi-arid unsaturated zones including but not limited to cave environments. A heap of 2,600 charred seeds of horsebean (Vicia faba L.) has been found in ancient dwellings at Yiftah'el near Nazareth in Israel. The beans date from 6,000 to 6,500 B.C. and surprisingly were not damaged by insects (Kislev, 1985). Ten thousand year old wood dowel, cord, and wood batten are reported from Guitarrero Cave in Peru, where arid conditions also led to preservation of textiles and domesticated plants (Lynch and others, 1985). In areas of extreme aridity, such as along the coast of Chile, 4,000 to 8,000 year-old mummies have been discovered in shallow burial pits (Allison, 1985); some of these mummies were naturally preserved, 
whereas others show that the skills of mummification were well-known to these people several thousand years before the earliest known Egyptian mummies .

Jumping forward in time several thousand years, we cite the amazing preservation of the Dead Sea scrolls placed in simple clay jars in shallow caves nearly 2,000 years ago (Pfeiffer, 1969). Nearby, at Masada, in Israel, beautifully preserved cloth, leather sandals, plaited hair, food (walnuts, dates, grain, and pomegranates), frescoes, and colored mosaic stone floors occur within a few meters of the surface of this butte; these materials date from about 70 A.D. (Yadin, 1966). The above examples, only a small fraction of those known, are cited to demonstrate the amazing preservation of even delicate organic and inorganic objects placed in the unsaturated zone at shallow depths and generally without intent of preservation on the part of our ancestors. We turn next to a few examples of deliberate and elaborate attempts by ancient man to preserve objects of importance.

Wacks and others (1981) briefly describe several examples of the excellent preservation of a variety of objects placed within carefully designed structures built by the Egyptians, Chinese, and Indians in the period 3,000 B.C. to 1,000 A.D. For example, portions of the funeral barque of Cheops (about 2,600 B.C.), buried in an rectangular pit in limestone and tightly sealed by limestone blocks and gypsum, were found in excellent condition in 1954; "even a $91 \mathrm{~m}$ (300 ft.) long rope and remnants of frayed fabric were found on the top deck" (Wacks and others, 
1981, p. 9). Although the rock Tombs of the New Kingdom, including that of Tutankhamen, were all ransacked, delicate objects of iittle value were left behind including robes, sandals, ostrich feathers and painted wall reliefs (Wacks and others, 1981, p. 51). In contrast, they (1981, p. 15) also report that some of the objects in the Tomb of King Tutankhamen had badly deteriorated due to periodic percolation of moisture into the tomb. The Chinese cave-temples at Ch'ien-fo-tung in Kansu Province at the edge of the Gobi Desert have yielded a spectacular library of 1,000-year-old manuscript rolls, silk banners, and paintings on linen or silk gauze (Wacks and others, 1981, p. 25). They report the climate of Ch'ien-fo-tung to be similar to that of northern Nevada. In contrast, they found that preservation of objects was generally poor in Indian temples constructed in the basaltic Deccan Traps because of water seepage and structural weakness (Wacks and others, 1981, p. 46); these structures are all located in presently humid climates. Based on their brief review of these and other "time-tested underground structures", Wacks and others concluded (1981, p. 54), as had hydrogeologists before them (Winograd, 1972, 1974), that solidified low-level radioactive wastes might be safely emplaced in a "rock-hewn waste complex" within a thick arid unsaturated zone provided special attention is given to prevent future human intrusion.

Based on the above cursory examination of the archaeological record, it appears that a detailed synthesis of this record--with special reference to the past and present physical setting of each site--can provide us with qualitative, yet highly pertinent, analogs of the likely long-term fate of solidified toxic wastes buried in unsaturated zone environments. 
Such a synthesis would seek to identify not only durable objects which have survived the tests of time, but also delicate ones. It would attempt to unravel the features of the physical environment that led to excellent preservation of parchment in one cave, while permitting poor preservation in an adjacent cave. It would attempt to relate preservation of delicate objects to the original and subsequent climates, as well as to the geomorphic and hydrogeologic setting of sites. The objective of such a synthesis is no less than an attempt to understand the physical, chemical, and biological factors leading to preservation of fragile, as well as durable objects buried in arid to semi-arid (and even sub-humid) unsaturated zones by Late Paleolithic to Iron Age man.

There are serious difficulties with arguments by analogy with the archaeological record. First, past climatic conditions at archaeological sites cannot easily be determined, and probably differed from present conditions. Second, it is unlikely that the hydrogeologic setting of the better-studied archaeological sites will exactly match those of any unsaturated zone site currently in use or being evaluated for receipt of toxic wastes. Third, unlike wastes in a high-level radioactive waste repository, archaeological remains were never subject to a heat pulse of a few hundreds of degrees centigrade, nor to intense radiation fields. 3

3 Though temperatures of one hundred to several hundred degrees centigrade still appear in the high-level radioactive waste literature, current thinking (Bredehoeft and others, 1978; Swedish Nuclear Fuel Supply Co., 1983) favors keeping the temperatures well below $100^{\circ} \mathrm{C}$ in order to reduce anticipated thermo-mechanical problems in repository construction and long-term performance. For nonradioactive toxic wastes, elevated temperatures and radiation would not detract from analogies with the archaeological record. 
Lastly, archaeological records, like stratigraphic records, are incomplete. (See Ager, 1981, for a very pertinent discussion of the incompleteness of stratigraphic, and by analogy of archaeological, records.) Thus the archaeological record may be strongly biased toward successful preservation, the unsuccessful ones leaving no exciting finds to be described. Nevertheless, the large number of unsaturated-zone archaeological sites, their occurrence in Holocene and Pleistocene climates ranging from arid to humid, and the great variety of materials buried in them should permit us to glean a wealth of qualitative to semiquantitative information bearing on the preservation and relative weathering of materials in unsaturated-zone environments over millenia to tens of millenia. Such a synthesis can provide an independent "as built" evaluation of the efficacy of the unsaturated zone under what can only be viewed as worst-case conditions; that is, early man's burial of unshielded objects at shallow depths or his subsequent "engineered" emplacement of precious objects that invited repeated entry into his structures by thieves. In contrast, solidified toxic wastes of low solubility presumably will be emplaced in the unsaturated zone at depths of tens to hundreds of meters, will be encapsulated in low-solubility containers, and the burial chambers designed to conduct vadose water around the waste containers (Winograd, 1974, 1981; Roseboom, 1983).

The proposed synthesis of the archaeological record admittedly is likely to yield only qualitative information regarding the expectable fate of materials buried in the unsaturated zone over times of millenia. Yet 
such a synthesis can constitute an invaluable supplement to computer-model generated "predictions" which, though quantitative, cannot be evaluated in the absence of an empirical data base.

There is a second major benefit that may be derived from a broad examination of the archaeological record; namely, providing the public and the courts with a readily understood basis for waste disposal in arid unsaturated zones. Public perception and acceptance is critical to any successful waste-disposal program. Yet, the ability of the public and the legal community to understand the results of interdisciplinary computerfmodels--however well accepted they may be in the scientific community--is probably limited. And, in all likelihood, there will not be unanimity within the scientific community about the suitability of any single model--a not unexpected occurrence in view of the transscientific nature of the problem and a situation unlikely to lead to scientific credibility with the public. On the other hand, the public and the courts are likely to more readily associate with a qualitative but strong analog approach, which a detailed examination of the archaeological record can provide. The archaeological record is something the public can nearly touch or see and therefore find more credible than computer-generated numbers of perceived mysterious origin. At the same time, the archaeological analog explicitly acknowledges one of the most serious reservations about toxic-waste disposal, especially shallow (less than 50 meter depth) disposal; namely, the potential for intrusion by our unaware descendants (see below). 
In summary, the archaeological record examined does, in general, sustain the preliminary favorable conclusions of earth scientists regarding the utility of arid and semi-arid unsaturated zones for safe burial of solidified toxic wastes. This record provides an invaluable, though qualitative, supplement to the quantitative, but untestable, computer-generated "predictions" of the long-term effects of the buried wastes on the hydrosphere and biosphere. Once the trans-scientific nature of the toxic-waste disposal problem is understood, the qualitative conclusions derivable from the archaeological record may suffice to convince the public that solidified toxic waste can be safely isolated from the environment by burial in carefully chosen thick unsaturated zones. Certainly modern man should be able to equal and improve upon the practices of his ancestors in his attempt to isolate solidified toxic wastes from the environment for millenia to tens of millenia.

A detailed synthesis of the archaeological record--done by archaeologists and Quaternary geologists with toxic-waste disposal in mind--is needed to verify the generally favorable prognosis presented herein concerning the long-term isolation of solidified toxic wastes buried at depths of tens of meters in the unsaturated zones of arid regions. 


\section{Future Human Intrusion Into Toxic Waste Burial Sites}

The potential for future human intrustion into toxic-waste burial sites has been of major concern to advocates of geologic disposal of radioactive wastes for more than a decade (Weinberg, 1972). Winograd (1981, p. 1462) explicitly acknowledged that of all the technical issues involved in an evaluation of thick unsaturated zones as toxic waste repositories, "the matter of future human intrusion is the crucial unresolved and perhaps unresolvable issue." Wacks and others (1981) also were greatly concerned with intrusion. They stated (1981, p.15), "If the analogy between the Egyptian royal tombs and the modern nuclear burial ground is correct, simple thievery and vandalism may be more of a threat to the repository than natural phenomena such as earthquakes and floods." A site chosen for waste burial must not be associated with known ore deposits or aquifers, but given these obvious exclusions, how can we prevent future discovery of, intrusion into, and perhaps even utilization of the wastes by our "unaware" descendents. Archaeologists began to address this matter a few years ago (see, for example, the papers by Cameron (1981), Kaplan (1982), and Battelle Memorial Institute (1984)). Topics studied included: the geometric placement of warning markers; the languages and symbols to be utilized on the markers; and the endurance or physical integrity of marker materials over millenia. It can be argued that warning markers exterior to a repository will ultimately invite vandalism (and possibly intrusion) after institutional control of a site is lost, and therefore, that such markers may prove to be counter-productive. In contrast, a series of warning markers within the passages leading to the burial 
site or repository appear essential to warn our unaware descendants of potential danger in the case of intrusion. Additional debate on the wisdom of external markers appears in order.

The matter of the physical integrity, over periods of millenia, of materials used for warning markers is clearly part of a third broad area in which archaeology can contribute significantly to toxic-waste disposal and to which we turn next. 


\section{Identification of durable natural and man-made materials}

A major research effort sponsored by the U.S. Department of Energy (DOE) and its predecessors, Energy Research Development Administration (ERDA) and the Atomic Energy Commission (AEC), during the 1960's and 1970's and continuing today, involved the identification of the best types of glass into which reprocessed nuclear wastes could be incorporated. 4 Sought was a glass with very low solubility that would resist devitrification for millenia even when subjected to temperatures of several hundred degrees centigrade. This research, which also includes evaluation of synthetic rock, has spawned a large literature. The Materials Research Society devotes a number of symposia to this topic at its annual meetings; with the results published annually in the book series "Scientific Basis for Nuclear Waste Management" (Plenum Press; North-Holland Press, volumes 1-7, 1978-1984). Relatively little attention, however, has been given to utilizing the state of preservation of dated man-made glasses and ceramics, from the archaeological record, as clues to selection of durable materials for waste containment. Notable exceptions are the reconnaissance studies of Kaplan (1982) and Kaplan and Mendell (1982), which contrast the state of preservation of glasses of varying ages and from different climates and the work of Roy and Langton (1983) who studied the

4 Although the disposal of spent fuel, rather than a glass waste form, has received major attention in the past 4 to 5 years, spent fuel may be placed within a "waste package", the design of which can benefit from the considerations raised herein. More important, we are looking for time-proven materials for the encapsulation of a variety of toxic wastes. 
characteristic of ancient mortars and plasters dating to 5,500 B.C. Further, the geologic literature has also not been fully utilized by wastedisposal technologists, for clues regarding rates of weathering of natural glass and selected rock types. Such literature presently exists (Friedman and Long, 1976; Steen-McIntyre, 1975; and Colman and Pierce, 1981).

Clearly there is a joint role in this area of study for archaeologists, materials scientists, and Quaternary geologists to compare and contrast the extent of weathering of durable natural and man-made materials as a function of age, climate, geomorphic-hydrologic setting, and burial environment (mausolea, soil zone, colluvium, cave, rock shelter, tunnel, etc., etc.). Additionally, detailed petrologic and geochemical studies might well reveal the amounts and perhaps even rates of leaching of selected elements from dated rocks, minerals, and man-made objects buried in unsaturated (or saturated) zone environments over time frames pertinent to the isolation of toxic wastes. 5 Such information would be of immediate interest to waste-disposal technologists for two purposes: (a) identification of new materials into which toxic wastes might be incorporated (via solid solution) or encapsulated (that is, used to surround the waste, forming the so-called "waste package"); and (b) selection of durable rocks for fabrication into monoliths capable of marking disposal sites for millenia.

5 For example, a study contrasting the weathering of an inclined vitrophere below and above the water table at a single location, could provide a wealth of information concerning relative leaching of selected elements in these two adjacent, but hydrologically different, environments. 
A "defense in depth" approach is wisely being utilized in evaluation of several sites for the disposal of high-level radioactive wastes, and hopefully the same approach will be used in selection of new sites for land disposal of the most toxic nonradiogenic wastes. The results of laboratory and short term field experiments on the multiple barriers at each site will be used, via interdisciplinary mathematical models, to predict the fate of buried wastes for periods of millenia and longer. Such analyses are justifiable and challenging, but their results must be used with extreme caution in view of the limitations in geologic prediction of even far simpler systems. Clearly, the task of predicting the effects of buried toxic wastes on the environment is a trans-scientific one. Yet, the Late Paleolithic to Iron Age record of man's inadvertent or intentional use of the unsaturated zone for preservation of a large variety of objects has the potential of serving an an invaluable analog of the likely fate of solidified toxic wastes buried in arid and semi-arid environments. The archaeological record is incomplete, is qualitative, and its transference to waste disposal is subject to the limitations of all arguments by analogy; nevertheless, it provides a real "data set" upon which to formulate an independent and favorable appraisal of the general ability of thick unsaturated zones in arid regions to isolate solidified toxic wastes from the hydrosphere and biosphere for millenia and beyond. Moreover, such an appraisal can probably be comprehended far more easily by the public and the courts than the numerical output of sophisticated interdisciplinary models of the fate of buried toxic waste. 
Archaeological science can also make substantial contributions to the related important matters of preventing future human intrusion into toxicwaste burial sites, choice of solids in which toxic wastes can be incorporated or encapsulated, and choice of rocks from which durable warning markers can be constructed. 


\section{ACKNOWLEDGEMENTS}

I thank E-an Zen and Newell J. Trask for informal reviews of an early draft and Gordon B. Bennett, George A. Dinwiddie, Curtis E. Larsen, James R. Rollo, and E-an Zen for helpful suggestions pertinent to the final draft. I thank James G. McCray for calling my attention to an important unpublished paper by Wacks and others (1981) which clearly recognized the potential utility of archaeology to selection of sites for the disposal of low-level radioactive wastes. My paper is an outgrowth of talks given in January 1984 and January 1986 at University of Arizona workshops on the physics and chemistry of contaminant transport through the unsaturated zone. 


\section{REFERENCES CITED}

Ager, D.V., 1981, The nature of the stratigraphic record: J. Wiley and Sons, New York, 122 p., $2^{\text {nd }}$ edition.

Allison, M.J., 1985, Chile's ancient mummies: Natural History, v. 94, no. 10, pp. 74-81.

Battelle Memorial Institute, 1984, Reducing the likelihood of future human activities that could affect geologic high-level waste repositories: Office of Nuclear Waste Isolation, Battelle Memorial Institute Report BMI/ONWI - 537, 129 p.

Bradbury, R.H., Hammond, L.S., Reicheu, R.E., and Young, P.C., 1983, Prediction versus explanation in environmental impact assessment: Search, v. 14, pp. 323-325 (Discussion by I.R. Kennedy in v. 15, pp 219-222).

Bredehoeft, J.D., England, A.W., Stewart, D.B., Trask, N.J., and Winograd, I.J., 1978, Geologic disposal of high-level radioactive wastes-Earth-Science Perspectives: U.S Geological Survey, Circular 779, $15 \mathrm{p}$.

Cameron, F.X., 1981, Human intrusion into geologic repositories for high-level radioactive waste: Potential and prevention: Radioactive Waste Management, v. 2, no. 2, pp. 179-187.

Cohen, B.L., 1982, Effects of ICRP publication 30 and the 1980 BEIR report on hazard assessments of high-level waste: Health Physics, v. 42, p. $133-143$.

Colman, S.M. and Pierce, K.L., 1981, Weathering rinds on andesitic and basaltic stones as a Quaternary age indicator, Western United States, U.S. Geological Survey Professional Paper 1210, 56 p. 
Friedman, Irving and Long, William, 1976, Hydration rate of obsidian: Science, v. 191, pp. 347-352.

Garisto, N.C. and Lyon, R.B., 1984, Environmental modelling and geologic disposal of nuclear fuel waste, in, Short Course in Environmental Geochemistry, M.E. Fleet, editor: Mineralogic Association of Canada, Short Course Handbook, v. 10. ch. 9, pp 217-235.

Interagency Review Group on Nuclear Waste Management, 1978, Isolation of Radioactive Wastes in Geologic Repositories: Status of Scientific and Technological Knowledge, in, Alternative technology strategies for the isolation of nuclear waste: National Tech. Information Services Rept TID-28818 (Draft), Appendix A, 89 p.

Kaplan, M.F., 1980, Characterization of weathered glass by analyzing ancient artifacts: in Scientific Basis for Nuclear Waste Management, C.J.M. Northrup, Jr. ed; Plenum Press, New York, v. 2, pp. 85-92. Kaplan, M.F., 1982, Archaeological data as a basis for repository marker design: Office of Nuclear Waste Isolation Rept. ONWI-3541, 92 p. Kaplan, M.F. and Mendel, J.E., 1982, Ancient glass and the safe disposal of nuclear waste: Archaeology, v. 35, no. 4, pp. 22-29.

Kislev, M.E., 1985, Early Neolithic horsebean from Yiftah'el, Israel: Science: v. 228, pp. 319-320.

Konikow, L.F. and Patten, E.P., Jr., 1985, Groundwater forecasting, in, Hydrological Forecasting, M.G. Anderson and T.P. Burt, editors: John Wiley and Sons, Ltd., New York, Ch. 9, pp. 221-270.

Lambe, T.W., 1973, Predictions in soil engineering: Geotechnique, v. 23, no. 2, p. 149-202.

Leakey, R.E., 1981, The making of mankind: E.P. Dutton, New York, 256 p. 
Leonards, G.A., 1982, Investigation of failures: Jour. Geotech, Engr. Div., Amer. Soc. Civil Engr., ASCE, v. 108, no. GT2, pp. 187-246. Lynch, T.F., Gillespie, R., Gowlett, J.A.J., and Hedges, R.E.M., 1985, Chronology of Guitarrero Cave, Peru: Science, v. 229, pp. 864-867. Materials Research Society, 1984, Scientific Basis for Nuclear Waste Management VII, G.L. McVay, ed.: North-Holland, New York, 1099 p. Mayr, Ernst, 1961, Cause and effect in biology: Science, v. 134, p. $1501-1506$.

National Academy of Sciences, 1983, A study of the isolation system for geologic disposal of radioactive waste: National Academy Press, Wash, D.C., 345 p.

National Research Council, 1983, Management of hazardous industrial wastes: Research and development needs: National Materials Advisory Board, National Academy Press Pub. NMAB-398, 76 p.

Peck, R.B., 1980, "Where has all the judgment gone?", The fifth Laurits Bjerrum memorial lecture: Canadian Geotech. Jour., v. 17, pp. 584-590.

Pfeiffer, C.F., 1969, The Dead Sea Scrolls and the Bible: Weathervane Books, New York, 152 p.

Roseboom, E.H., Jr., 1983, Disposal of high-level nuclear waste above the water table in arid regions: U.S. Geological Survey Circular 903, $21 \mathrm{p}$.

Ross, B., 1986, Scenarios in performance assessment of high-level waste repositories: Radioactive Waste Management and the Nuclear Fuel Cycle, v. 7, no. 1, pp. 47-61 
Roy, D.M. and Langton, C.A., 1983, Characterization of cement-based ancient building materials in support of repository seal materials studies: Office of Nuclear Waste Isolation, Battelle Memorial Institute Rept. BMI/0NWI-523.

Scriven, Michael, 1959, Explanation and prediction in evolutionary theory: Science: v. 130, pp. 477-482.

Simpson, G.G., 1970, Uniformitarianism: An inquiry into principle, theory, and method in geohistory and biohistory, in, Hecht, M.K. and Steere, W.C., eds., Essays in evolution and genetics in honor of Theodosius Dobzhansky: New York, Appleton-Century-Crofts, pp. 43-96. Steen-McIntyre, Virginia, 1975, Hydration and superhydration of tephra glass--A potential tool for estimating age of Holocene and Pleistocene ash beds, in, Quaternary Studies, R.P. Suggate and M.M. Cresswel1, eds.: Royal Soc. N. Zealand, Wellington, pp. 271-278. Swedish Nuclear Fuel Supply Company/Division KBS, 1983, Final storage of spent nuclear fuel-KBS-3: Swedish Nuclear Fuel Supply Co/Division KBS, ch. 1, p. 4.17-4.19.

Tyler, L.D., Peters, R.R., Hayden, N.K., Johnstone, J.K., and Sinnock, S., 1984, NNWSI performance assessment considerations, in, Scientific Basis for Nuclear Waste Management VII, G.L. McVay, ed.: NorthHolland Press, New York, pp. 327-344.

Wacks, M.E., Kuck, P.H., Matloubieh, A.Y., and McCray, J.G., 1981, Timetested underground structures suitable for isolating low-level waste: Engineering Experiment Station, University of Arizona mimeographed report prepared for the Los Alamos Scientific Laboratory under Contract $4-\mathrm{N}-20-0328 \mathrm{~N}-1,56 \mathrm{p}$. 
Weinberg, A.M., 1985, Science and its limits: The regulator's dilemma: Issues in Science and Technology, v. 2, no. 1, pp 59-72. Winograd, I.J., 1972, Near surface storage of solidified high-level wastes in thick (400-2,000 feet) unsaturated zones in the Southwest: Geological Society of America, Abstracts with Programs, v. 4, no. 7, p. 708-709.

Winograd, I.J., 1974, Radioactive waste storage in the arid zone: EOS, Transactions American Geophysical Union, v. 55, no. 10, pp. 884-894 (Discussion in v. 57, no. 4, p. 178, 215-216).

Winograd, I.J., 1981, Radioactive waste disposal in thick unsaturated zones: Science, v. 212, no. 4502, pp. 1457-1464 (Discussion in v. 215, p. 914$)$.

Wollenberg, H.A., Yang, J.S.Y., and Korbin, G., 1983, An appraisal of nuclear waste isolation in the vadose zone in arid and semi-arid regions: Lawrence Berkeley Laboratory Rept. LBL-15010, 126 p. Yadin, Y., 1966, Masada: Random House, New York, 272 p. 